\title{
STATE AND INDUSTRY IN THE 1940s:
}

\section{The Spanish Automobile Industry ${ }^{*}$}

\author{
S. Estapé-Triay \\ Department of Economics and Business \\ Universitat Pompeu Fabra \\ C/ Ramon Trias Fargas, 25-27 \\ 08005 Bacelona \\ salvador.estape@econ.upf.es
}

\begin{abstract}
The decade of the 1940s was one of the darkest periods in the country's history, with years of famine, repression, general misery, and impoverishment of all aspects of national life ranging from culture to the economy. During those years plans were made to establish a Spanish motor industry once the Civil War had come to an end in 1939. It seemed a propitious moment for private enterprise and various foreign motor companies presented proposals for manufacturing their entire vehicle range, from cars to trucks. However, the government plans were for a State monopoly, a policy which meant that any private projects which did not contemplate the regime taking management decisions were rejected out of hand. From 1941 onwards, any new initiative was required to meet the plans set by INI. The main argument running through this paper is that one can only understand the development of the modern Spanish motor industry if one grasps the haggling between motor companies and government regarding market entry and the impact of the regime's autarchic policies in the 1940s.
\end{abstract}

Keywords: autarchy, monopoly, motor industry, state intervention

JEL: L1, L2, L62, N64

" Paper to be presented at the Third Conference of the European Business History Association, Rotterdam, The Netherlands, 24-26 September 1999 


\section{INTRODUCTION}

The founding of the SEAT motor company represented a watershed in the Spanish automobile industry. Most attention has been focussed on the second half of the $20^{\text {th }}$ century. This is hardly surprising since the industry's development during this period took off: after SEAT came Fasa Renault, Citroen, Peugeot, Ford, and General Motors, laying the foundations of the present industry which is wholly controlled by the subsidiaries of large multinationals. However the relative scarcity of vehicles before the key events of the 1950s [G arcía D elgado, 1987, p. 170] should not blind us to some important developments in the 1940s. Looking back at the first half of this century one can appreciate how the Civil War splits the period. Multinational subsidiaries also dominated the market before the war, with just a few local companies whose impact was minimal. In contrast, the immediate post-war period saw the disappearance of G eneral Motors Peninsular from the scene while Ford Motor Ibérica ended the war severely weakened. From that point on and for the rest of the early period of the Franco dictatorship, the motor industry was marked by a series of projects (only some of which were viable) and a fascinating interplay between state and private initiative. This marriage of convenience spawned companies whose "modus vivendi" gives valuable insights into this period of Spanish history.

The decade of the 1940s was one of the darkest periods in the country's history, with years of famine, repression, general misery, and impoverishment of all aspects of national life ranging from culture to the economy. The country experienced a severe slump [Carreras, 1989] throughout the decade. Industry, while not severely affected by the war itself, proved incapable of taking advantage of Spain's neutrality during the Second World War [Catalan, 1989, 1995] and suffered a significant fall in production levels [Carreras, 1989]. Production levels, sales, and vehicle registrations revealed the virtual standstill in the sector. The recovery did not begin until the middle of the 1950s. It was only then that the first faltering steps were taken to modernise the economy, a process that gathered steam in the last half of the $20^{\text {th }}$ century. However, this paper sets out to delve into the grim $40^{\prime}$ s, which Carreras has called "the long night of Spanish industry" [Carreras, 1984, p. 147].

Plans were made to establish a Spanish motor industry once the Civil War had come to an end in 1939. It seemed a propitious moment for private enterprise and various foreign motor companies presented proposals for manufacturing their entire vehicle range, from 
cars to trucks. However, the government plans were for a State monopoly, a policy which meant that any private projects which did not contemplate the regime taking management decisions were rejected out of hand. From 1941 onwards, any new initiative was required to meet the plans set by INI (National Institute of Industry) ${ }^{1}$. Virtually all vehicles in Spain had been imported or assembled by multinational subsidiaries before the war. However, from 1939 the new regime refused to accept assembly operations, and insisted that any company wishing to set up factories would have to carry out the whole manufacturing process in Spain. Naturally, the idea of achieving total autarchy was absurd, given that a nationalisation policy of this kind needed foreign co-operation. Spanish industry on its own simply did not have enough technological know-how to embark on vehicle production by itself, particularly with regard to cars. On the other hand, any foreign collaboration was expected to meet the autarchic framework set by the new fascist government. One should not forget here that the new regime tried out autarchic policies in the first few years of power and deliberately subordinated economic interests to military ones in so doing.

The main argument running through this paper is that one can only understand the development of the modern Spanish motor industry if one grasps the haggling between motor companies and government regarding market entry and the impact of the regime's autarchic policies in the 1940s. Studies on the industry have generally centred, as San Román [1995, p. 141] suggested, on the quantitative contribution made by the sector to economic growth. Such an approach inevitably focuses on development from the 1950s onwards and thus starts from the establishment of SEAT and Fasa-Renault. However, work in the last decade, based on data from the INI archives, has provided us with much greater knowledge of the development of the motor industry in the years before the establishment of SEAT [San Román, 1995; López Carrillo, 1996; Estapé-Triay, 1998b]. We have already mentioned how the Civil War marked a halt to the formation of a national motor industry based on foreign investment (mainly by Ford, General Motors and Fiat) and the beginnings of strong State intervention [Estapé-Triay, 1997, 1998a]. This is why studies of the industry should not be limited to the period following the inauguration of the SEAT factory. To do so would be to ignore two decades in which the motor industry might have developed in very different ways. Thus, although it is not our intention to rewrite history, it is only by examining plausible alternatives that we can fully understand what actually happened. As Ferguson [1997] puts it, the historian should not allow his knowledge of what actually happened to blind him to what people at the time thought 
would likely happen. To do so makes it more difficult to grasp a past reality and simply falls into the "inevitability trap".

Thus this paper sets out to analyse what happened in a key industry during the first decade of the Franco regime. Once again, one can only stress the late development of the motor industry in Spain and the fact that the country only managed to produce one modern manufacturer of its own: SEAT. However, one should not ignore some of the initiatives during the first half of the century [Estapé-Triay, 1998]. This backwardness and the painful slowness in setting up a national motor industry only tend to reinforce the grim impression one gets of Spain in the 1940s [Fontana, 1986; García Delgado, 1987, 1989; Catalan, 1995]. The new regime had already begun to realise the importance and need for a strong motor industry in the period immediately following the war, although it should be said that this appreciation was highly coloured by a military and autarchic considerations. Particularly noteworthy among the first projects (most of them private) was SIAT [San Román, 1995], in 1940. Despite its initially private nature, INI quickly took over the project and overall development and manufacture of vehicles. Other projects soon appeared on the scheme backed by Alfa Romeo, Lancia, Saurer, Hispano-Suiza, given that truck building was another challenge and represented a more immediate need. However, be this as it may, the most important venture was the SIAT-FIAT one for the manufacture of cars and which sowed the seeds of SEAT ${ }^{2}$. The first contacts between the new fascist government and the Italians began in 1941. The purpose of this paper is to delve into this negotiation and place it within the framework of Franco's plans for industrialisation on autarchic lines.

The planning and setting up of the motor industry in the years spanning 1939 to 1954 falls into five well-defined stages. The first ran from the end of the Civil War to the setting up of INI and was characterised by the presentation of the first private groups, the most noteworthy being those of Bank of Urquijo Group and FIAT (SIAT). The second stage began when INI joined the latter project, which became a joint venture by INI, FIAT, and Urquijo. Other projects also appeared on the scene, the Alfa Romeo-INI-Hispano Suiza one being particularly important with regard to truck making. The third stage covers the period 1944-46 when INI was forced to break off collaboration with Italy as a result of the war. There was a switch in priorities to truck production, with collaboration between Hispano-Suiza and INI for this purpose. This stage came to an end with the creation of ENASA in 1946. One should also briefly mention a private venture - EUCORT, of 
which more will be said later. The fourth stage covers 1947-49, during which Banco Urquijo again took up the reins of the SIAT car project. However INI once again insisted on the need for State involvement. Finally an agreement was signed between INI and FIAT in 1949 which established the SEAT company. SEAT car production began in the period 1950-1954, which also marked the post-war consolidation of the Franco regime. There were also other initiatives such as the Fasa-Renault one and a tractor project involving private enterprise (Motor Ibérica). In short, the first steps in establishing a Spanish motor industry had been taken within the framework of extremely interventionist government policies.

This paper has been organised as follows. The second section deals with the situation prior to the outbreak of the Civil War, characterised by a slow process of adaptation to local conditions and the domination of multinational subsidiaries, the most important of which were Ford Motor Ibérica, G eneral Motors Peninsular and Fiat Hispania [Estapé-Triay, 1998]. The third section deals with the body blow dealt to American subsidiaries by the Civil War and the fascist victory. The fourth and fifth sections cover private proposals for vehicle manufacture in which I will argue that: INI's obsession with total control of any kind of project; forced siting of factories in areas miles away from production centres; sheer obstinacy in maintaining the Italian option; and interminable negotiations between INI and private companies, all helped stifle the industry's development for during the first post-war decade. While it is true that the Second World War was a setback for the incipient Spanish motor industry, it is far from being the only reason for Spain's backwardness at the time. I agree with San Román when she says that private initiative was held over a barrel by the vaunting ambition of INI [San Román, 1995, p. 161]. However, the EUCORT case does not entirely fit this general observation since the initiative received very little in the way of official support and was ill-defined. What is certainly true is the way in which the country was "cleansed" of foreign companies throughout the 1940s - General Motors Peninsular did not survive the Civil War, while Ford clung on until the early 1950s, finally giving up the ghost in 1954, tired of the regime's endless interference with private initiative.

\section{THE “NATURALISATION” OF THE MOTOR INDUSTRY, 1923-36}

Local automobile production was one of the biggest problems facing the Spanish economy in the inter-war period. Hence the search for a solution by successive governments. State protection of the motor industry started with the passing of the 
Decree of the $9^{\text {th }}$ April 1927 in which the Primo de Rivera dictatorship set out its plan to nationalise vehicle manufacture. This was followed by a government law which granted the State a minimum $5 \%$ per cent stake in capital invested in vehicle manufacture. The ineffectiveness of these provisions and the world slump forced the Berenguer government to enact the so-called "Wais law" which raised tariff barriers on foreign vehicles, partly to stimulate domestic production but above all to stem a flood of imports which would have wrecked the trade balance. The Republic rescinded the law but was quickly forced to introduce import quotas to fulfil the same objectives. Finally, the so-called "Vehicle Laws" (Leges di Automóil ) were enacted on the $3^{\text {rd }}$ July and the $2^{\text {nd }}$ December 1931 and whose purpose was to achieve 70\% nationalisation of vehicle manufacture. Ford Motor Ibérica operated under these provisions, using components produced by Spanish ancillary industries. Other companies like G eneral Motors and SEIDA adopted a similar policy and enjoyed limited success ${ }^{3}$.

The development of the industry throughout the first third of the century lagged far behind the rest of Europe. Two reasons have traditionally been given for the weak development of the Spanish motor industry. The first concerns the small domestic market and purchasing power, which hampered the adoption of mass production. Although high quality vehicles were turned out, they were simply too expensive to compete with foreign vehicles. The second factor was Spanish "workshop" manufacturing methods which, while of high quality, were unable to deliver the technology and design know-how of foreign manufacturers. The government sought to solve these problems by irreversibly nationalising the industry and implementing an interventionist policy. The government's economic policy-makers believed the domestic market's limited capacity to absorb vehicles could be resolved by rationalising both the number of models produced and the manufacturing system. The policy boiled down to reducing the number of factories and concentrating production to achieve much longer production runs. The examples which the government sought to emulate were the German and Italian industries. It was emphasised that "the greater the reduction and simplification of models, the closer we will get to the manufacturing systems employed in these countries and hence the cheaper vehicles will be to produce". Furthermore, it was considered the absence of a motor industry in Spain would avoid the "drawbacks" of dealing with "vested interests" in deciding the best industrial organisation for vehicle production. Manufacturing was therefore planned according to the following scheme: a) a single factory turning out basic cars, on the lines of the model adopted in Italy where Fiat covered the bulk of national 
demand for this type of vehicle with 1.1 and 1.5 litre "Topolino" models; and b) a sole truck factory producing two basic goods vehicles.

In addition, technological backwardness meant collaborating with foreign companies, which the Law of the $24^{\text {th }}$ November 1939 stipulated "shall not prejudice the legal rights of Spanish capital invested in the company concerned". However, it was not simply a question of patent licensing but rather establishing collaboration on setting up a factory and ensuring a lasting link between the foreign and Spanish company to keep abreast with international technological developments in the motor industry. This way, the national company could continually improve its models. This approach implied that mere assembly operations on the lines of Ford Motor Ibérica or General Motors Peninsular would be rejected since they did not help Spain acquire modern technological know-how. The idea was to pay a fixed annual sum or royalties as a quid pro quo for foreign technology transfer.

These then, were the considerations which inspired the studies which formed the basis of the Decree of $10^{\text {th }}$ February 1940, whose provisions cut the number of factories and models to the bare minimum and set out the terms for foreign collaboration. However, the law did not deal with the problem of which model should be produced. Spain in particular had a big trade deficit in cars and had to import fuel. This made it advisable to manufacture low-consumption vehicles. It was therefore finally decided to concentrate manufacturing in a single factory, with an initial annual production of twelve thousand cars of less than 12 horsepower.

The pre-war Spanish motor industry had shown considerable capacity to supply vehicle components and spares, largely thanks to the partial nationalisation mainly tried with Ford Motor Ibérica (but also with other companies) [Estapé, 1998]. Ancillary industry supplies chassis, wheels, coach work, electrical equipment, radiators, headlights, etc. while motors and transmissions were built by the car factories. In other words, an attempt was made to extend the "Ford" model of collaboration to other companies, using this as a basis for nationalising the industry and tying in the assembly shop (supplied by ancillary industries) with the engine and transmission factory. Basically, the Franco regime's policy-makers were faced with two problems, as Table 1 shows. On the one hand they wanted to build on the experience gained in the sector to intensify assembly operations using locally supplied components and materials. In this respect they were merely following through 
the nationalisation policies of the Primo de Rivera dictatorship in the 1920s. On the other hand they needed to build an engine factory from scratch.

TABLE 1. Autarchic car production plan, 1941

\section{FOREIGN ENTERPRISE: FORD AND GENERAL MOTORS}

Before examining the SIAT, INI, Fiat and EUCORT cases, we should first look at Ford and General Motors, given that these were the first companies to approach the new regime with their projects for developing the motor industry in Spain. As has already been mentioned, both companies, but particularly Ford, had Spanish subsidiaries which were very active in the country before the outbreak of the Civil War. Thus Ford established its own factories in Spain in the 1920s, an extensive sales network, and participated actively in the partial nationalisation plan. It therefore had good reason to expect preferential treatment from the economic leaders in the new fascist government [E stapé-Triay, 1998].

Under the aforementioned partial nationalisation plan, Ford began to increase the proportion of Spanish materials used in its vehicles from 1932 onwards. The company already used 15 million Pesetas worth of Spanish materials by 1934. Ford's idea was to maximise the Spanish component in it vehicles. Thus by 1936, the Spanish content of each vehicle was at least $33 \%$ and some cases reached $50 \%$ to $60 \%$. The growth of production meant the company's factory in Avenida de Icaria, (Barcelona) could no longer cope with growth. Accordingly, Ford Ibérica's Board of Directors held various meeting throughout 1935 and 1936. It decided to build a modern new factory in the Barcelona Free Port, thus enabling assembly work to be carried out more cheaply and rationally than in the old Poble Nou plant. By installing plant imported from the States they would be able to mechanise production of more complicated vehicle parts. This would avoid having to assemble outside the plant, an option which was simply too expensive. The total cost of the project came to 9 million Pesetas, a figure which would be financed by ploughing back profits. This followed the Ford policy of investing in plant and equipment in their markets 5 . The zenith of nationalisation plans was reached in May 1936 when the Ford Board of Directors approved the building of the new factory in the Barcelona Free Port. Negotiations with the local authorities were well under way and American architects had arrived in the city to work on the plans. The factory was to cover 32,000 square metres and the investment would amount to eight million Pesetas in plant and two million Pesetas in machinery. Forecast output was 75 vehicles a day ${ }^{6}$. The new plant was initially intended 
to cover existing Spanish demand but the possibility of further extending the factory was not ruled out given that the site was double the built area. Ford's objective was to manufacture cars using almost 100\% Spanish materials, in the same way as in its factories in Germany, France, and England. This is borne out by the companies figures for Spanish purchases, which amounted to 4.4. million Pesetas (56\% of the total) in 1933 and 15.6 million Pesetas in 1935 (76\% of the total) with production of roughly 3,000 and 6,600 vehicles in those two years ${ }^{7}$, respectively. The Civil War put an abrupt end to these expansion plans.

The company had 750 staff in June 1936 but there were 2,500 people in ancillary industries working exclusively for Ford. The materials and components supplied to Ford by local industries included: tyres, inner tubes, batteries, chassis, front axles, windscreen wipers, windows, seats, upholstery, parts of the rear axle, motor parts, wheels, and coach work. The continuation of this policy of promoting national production would have meant reaching 70\% local content in vehicles at the Barcelona plant by June 1938, had the Civil War not broken out. Ford's plans also envisaged growth in the number of vehicles produced by other car companies in Spain. As the director of the subsidiary in his report on the company's activities during the Civil War noted, the firm's policies since 1932 had created new industries and stimulated others. Over two thousand people worked in ancillary industries and another two thousand in Ford's sales network. It should be recalled that Ford Motor Ibérica was not just a factory but the nerve centre for over two hundred strategically-sited concessionaires throughout Spain, selling vehicles and after-sales service. The network was financially controlled by Ford, even though the company did not directly own any of the concessionaires. Each dealer and sub-dealer had its own Ford-trained salesmen and mechanics.

Ford did not stop making vehicles during the Civil War. It continued assembling trucks throughout the post-war period and getting by with the sale of spares and accessories. However, the 1935 and 1936 expansion plans were scrapped entirely. Ford Motor Ibérica was condemned to play a lesser role during the 1940s, despite interminable negotiations throughout the period between the subsidiary, Ford in the U.S. and England on the one hand, and the Spanish government and INI on the other.

General Motors Peninsular fared differently. The company was wholly owned by General Motors and had an assembly plant and warehouse in Barcelona, as well as a network of 
one hundred and fifty dealers throughout Spain. It played a less important role in the motor industry during the inter-war period than Ford. The firm closed its Spanish plant two days after the outbreak of the Civil War. GM's property passed into the hands of a workers' committee on the $22^{\text {nd }}$ July 1936 which ordered the management off the premises. The company's bank accounts seized and despite protest by the management, paid workers salaries regardless of the work done. GM's Spanish assets fell under the control of the Catalan Government's "Anti-fascist Committee" on the $31^{\text {st }}$ July 1936. The plant was put back into operation a few days later and started assembling army trucks with the materials in the company warehouses. The company estimated losses as of $2^{\text {nd }} 0$ ctober 1936 at over 3.3. million Dollars. This figure did not include damage to the plant and machinery. Once the stock of components ran, truck assembly ground to a halt. The Catalan Government then converted the plant to a factory manufacturing munitions for war 'planes. Thus GM's Spanish subsidiary disappeared from the scene for the duration of the Civil War'.

However, in May 1939, the Managing Director of GM submitted a draft project for a factory producing cars and trucks within the framework of the Government's national industry protection scheme ${ }^{9}$. The Spanish government attached various conditions. The authorities were determined to choose a single manufacturer for the production of various truck and car types. In the beginning it considered 30 to 40,000 vehicles as the minimum acceptable. The regime believed the drawbacks of a monopoly would be more than offset by the "benefits" of military organisation of production. The setting up of the monopoly also involved applying a procrustean model of State enterprise so that all such companies employed a similar structure covering capital, bonds, minimum guaranteed interest, and possibly management incentives, as well as the conversion of bonds and shares once the industry was well-established and more freedom could be given to market forces. The company was to be run by people whom the regime trusted. Lastly, foreign investment was considered from three points of view: (a) technical, i.e. plans, patents, staff, etc., (b) machinery, and (c) financial (debentures and bonds). The agreements envisaged that exports could be considered once Spanish demand had been satisfied, with the foreign company being granted a bigger role within a new framework.

The GM representative argued that technical and/ or economic reasons ruled out manufacturing certain vehicle parts in Spain. The government replied tartly that "given the GM representative's statement to the effect that certain parts cannot be manufactured in Spain for technical/ economic reasons, we must point out that factories have to manufacture absolutely all vehicle parts (my emphasis) in the quantities required. Reducing the activity of certain sections or importing particular components is subject to 
government approval. The company shall put such sections into full production to guarantee vehicles are entirely manufactured in Spain, should the government deem this in the National Interest. It should be recalled autarchic consideration may be of greater importance than purely economic ones". (my emphasis). The authorities also emphasised "the government would brook no interference in policy matters". The regime also considered that GM has been "vague" with regard to possible sources of Spanish capital (March had made offers) and stipulated "that the capital of these types of companies must be wholly Spanish capital. No special capital provisions are therefore necessary and only present an obstacle to gaining project approval". ${ }^{10}$

\section{PRIVATE INITIATIVE: SIAT-FIAT, EUCORT}

SIAT $^{11}$ was the first Spanish project for setting up an automobile factory. The company proposed manufacturing a basic vehicle already produced by FIAT and which already satisfied most Italian demand. The car could therefore be adopted as a model for the Spanish market. It was planned that the license would cover fifteen years. FIAT had three factors in its favour. First, the make was well known in Spain and had built quantities similar to those envisaged for the proposed SIAT factory. Second, the Spanish market was similar to the Italian one, with low volume and poor consumers. Third, the fascist regime in Italy had given FIAT a monopoly of vehicles under 12 horsepower, which was also how things would work in Spain if SIAT were granted the concession. It boiled down to importing the Italian system lock, stock, and barrel - a policy which the Spanish regime considered to be in the national interest. On the technical side, it was not simply a question of licensing patents but rather of strong technological and financial collaboration between the Italian and Spanish companies.

The agreement between SIAT and FIAT involved the former paying the latter eight hundred thousand dollars in gold in return for a detailed project on the human, technical, and material resources for setting up the factory. FIAT's investment came to roughly $25 \%$ of SIAT's 125 million Pesetas of share capital. The Italian company would also receive a $3 \%$ patent royalty on the Spanish retail price of each vehicle. However, INI raised various objections from the outset. For example, without even questioning the 3\% royalty, INI considered the idea of incorporating a clause of this type in a contract of unlimited duration to be unacceptable. INI considered that SIAT should take up other national and foreign patents in addition to those offered by FIAT, and do so at the earliest opportunity. Yet another objection raised by the Institute was that if SIAT did not make a big effort to stimulate national ancillary industry, the vehicle venture might become little more than an assembly operation using foreign components. INI argued that it therefore had every right 
to intervene in the development of the project, stressing that the State nature of the body and its wide responsibilities for the Spanish economy put it in a position to "fully appreciate the possibilities of ancillary industries at any given juncture".

All of the private projects for vehicle manufacture involving foreign capital came to naught during the Second World War. However, there was one local initiative which was wholly funded by Spanish capital that actually managed to make vehicles. The company was EUCORT, an interesting case of a genuinely private initiative operating under an autarchic economic regime.

EUCORT was founded by Eugenio Cortés in October 1945 and was to be the only Spanish company in the 1940s which managed to produce vehicles. The initial investment was five million Pesetas and was used to purchase an old car repair workshop and a bodywork shop. The technical office was set up in the latter. The aim was to sell a small vehicle based on the German D.K.W. The company's activity was confined to building four prototypes in the first six months of its operation, which were then used for various tests (which mainly consisted of taking the vehicles out for a spin on the open road). By March 1946, the company finally had the machine tools to make certain components available. Cortés believed that he would soon be in a position to turn out fifty wholly Spanish vehicles a day with the machinery he already had, plus other items being manufactured or which could be bought in the country. His target sale price was 23,000 25,000 Pesetas. However, his initial capital proved woefully inadequate for funding his plans and accordingly Cortés decided to expand the share capital to 30 million Pesetas. To do so, he needed the Ministry of Industry's formal approval and for the project to be classified as "in the national interest". Cortés would thus have enjoyed preferential treatment when it came to supplies and taxes. His hopes of obtaining all his supplies from the Spanish market were wildly optimistic since a study carried out by INI and FIAT revealed that the financial and technological conditions for embarking on long production runs simply did not exist in Spain. The lack of specialised precision machinery was just one of the difficulties which crippled production.

Despite the meagre resources available, work at EUCORT went ahead and a limited company was set up in August 1946 ${ }^{13}$. The firm (which had to operated under a strict autarchic regime) had three main aims. These were to (1) achieve some kind of normality in the supply of vehicles, at a time when imports were severely restricted; (2) increase self- 
sufficiency in high demand sectors, eventually doing away with the need to import foreign vehicles; and (3) cover Spanish demand and export to other countries which did not have their own motor industries, particularly those "whose race and language offered the best openings" ${ }^{\prime 14}$ (my emphasis).

However, EUCORT's results failed miserably to live up to the optimistic forecasts. The vehicle had serious faults and the price was much higher than planned. Neither the machinery used nor the production plant were up to modern standards of vehicle production. The company remained severely undercapitalised, particularly when it is borne in mind that materials and labour costs alone came to over six million Pesetas a month. This was an extremely heavy commitment, especially when one considers the State had to re-examine the "national interest" (which formed the basis of the concession) at the end of just one year's operation. It was highly unlikely that a company with a capital of just 30 million Pesetas would be able to produce vehicles worth 150 million Pesetas a year. Accordingly, the Motor Vehicle Department of INI recommended the concession based on "national interest" be cancelled ${ }^{15}$. It did, however, advocate supporting the company's development and helping it with the supply of raw materials. The granting of a further "national interest" classification could then be re-examined at the end of another year ${ }^{16}$.

D espite EUCORT's slender resources and plant shortcomings, the firm was still better placed after its first year of operation (i.e. late 1947) than any other national vehicle manufacturer (for example the «Nacional Sitjes» organisation). On the dark side, the firm was still woefully equipped to undertake production in series. The truth of the matter was that both the plant and machines used could only turn out prototypes and very short production runs, but not mass-produced vehicles. We do not have access to the EUCO RT files and therefore we cannot say anything about the company's financial state of affairs. It also impossible to guess at the company's future since its plant provided little more than a timid learning experience in the sector. The comparative data in Table 2 lead one to concur with the evaluation made at the time by Wifredo Ricart of CETA (Centre for Vehicle Technical Studies) to the effect that the firm still had a very long way to go before it could produce a vehicle meeting the needs of the Spanish market. Thus EUCORT's "national interest" classification was withdrawn, despite the country's desperate need for vehicles and very strong domestic demand. The firm had showed initiative but it simply lacked the means to deliver cheap vehicles in lange quantities. Nevertheless, Ricart suggested taking advantage of EUCORT's efforts to date to build 
taxis, which would also avoid the company getting in the way of other initiatives which he considered more useful ${ }^{17}$.

This brought the first period in the company's existence to a close (spanning from mid1945 to the end of 1947). By the end of 1947 the company had the basic industrial plant to manufacture vehicles on a continual basis, once it produced prototypes, carried out testing, and set up its internal organisation and distribution network. However, it was not able to take on mass production.

January 1948 marked the beginning of the second stage in the firm's history. The company began making regular deliveries of its vehicles and was thus able to start selling its products on a serious basis. This state of affairs continued until mid-1949. The whole plant was renewed during this period and some special machines were built, particularly automata and virtually all the machine tools. All of the components required for die stamping had been supplied. Despite this, the company admitted that a high percentage of its production work continued to "use craft skills" since this was the only way it could make a profit (almost all of which was ploughed back into improving the plant). O nly two vehicles came off the production line a day. This was due to various causes, including electricity cuts which meant the machinery worked at only 40\% capacity. The sales network employed 22 independent dealers. The firm had sales, distribution, advertising, and customer service departments.

EUCORT now entered its third and terminal stage. The company's position just four years after its foundation was a critical one. The price of its vehicles was still considerably higher than the target set (see Table 2). EUCORT was only turning out four vehicles a day at best, although there were hopes of reaching twenty a day within a short time. Nevertheless, this was light years away from the production forecasts made three years earlier. The company's financial difficulties were the result of a wildly optimistic project for supplying a wholly Spanish vehicle with Spanish staff and materials in a country still reeling from the effects of the Civil War. The firm sought State aid to escape Nemesis. EUCORT applied for State funding to help it manufacture longer production runs in June 1949. ${ }^{10}$ All this took place shortly before Spain finally managed to mass produce its own vehicles ${ }^{18}$.

Several conclusions can be drawn from the company's history. First, the firm lacked the plant required to turn out vehicles in long production runs. It therefore resorted to craft 
methods and inappropriate technology. It needed a new factory with modern equipment if it was to implement mass production methods. If FIAT had to manufacture 12,000 vehicles a year to make production of its larger, more powerful models economic (see Table 2), EUCORT, as a smaller manufacturer, needed to produce more vehicles to competitively price its products. Assuming a minimum of twelve thousand vehicles a year had to be produced and the sales price could be reduced to 50,000 Pesetas, the company would have needed capital of 400 - 500 million Pesetas - a far cry from EUCORT's paltry 30 million. Table 2 shows the enormous gap between EUCORT's ambitions and the resources for attaining them. The company's request for State funding was therefore turned down. First, the then Vice-President of INI considered it inappropriate to provide any kind of financial aid to a company which, in his words, "received permission, once in operation, [...] to build 3,000 vehicles a year of various types [...] whereas production failed to reach the 1,000 mark. The authorisation explicitly specified that no guarantees were implied regarding Government measures for the protection and stimulation of the motor industry $^{19}$. Second, continuation of EUCORT's investment plans and authorisation of State funding could have made it difficult to get foreign exchange to carry out the factory project planned by INI with FIAT's support. Thirdly, given the limitations of the Spanish market, it had always been the policy to license manufacture of just a single national model to achieve long production runs. The official view was that "manufacture of a EUCORT car will therefore soon prove incompatible with production of a FIAT vehicle ${ }^{20}$. However, when in 1950, Cortés asked INI for 15 million Pesetas in return for winding up the company, Planell astutely replied that EUCORT's competition in the market would not interfere with the Institute's project, given the significant differences between the two vehicles ${ }^{21}$.

In conclusion, EUCORT took initial advantage of the strong demand for utility vehicles in the Spanish market, being able to sell these under monopoly conditions at very high prices. However lack of financial and technical resources constantly threatened the company's survival. Thus according to a bank report "Liquidity is low and the company is poorly placed to meet all its payment obligations, particularly when large sums (mainly covering general overheads) are involved [... ]. There is little general agreement concerning the company's founders and hence dealings with the company have always been conducted with caution. The firm's liquid assets have also been a weak point from the outset. We therefore council prudence, especially where significant risks are involved"22 It ought to be said in EUCORT's defence that the parlous situation in post-war Spain with 
shortage of foreign exchange, import restriction etc. would have threatened the survival of any similar venture.

TABLE 2. Comparisons between the size of EUCORT - planned and actual - and the SEAT project

\section{PUBLIC INITIATIVE: IN I-FIAT}

\subsection{The war years: 1939 - 1945}

Both autarchic and defence reasons lay behind the Spanish government's dogged desire to manufacture its own vehicles. The first Article in the legislation which established INI makes this objective crystal clear. Hence the Institute's deep conviction that it had a vital part to play in manufacturing cars. According to Suanzes, SIAT would end up being run as a private company if INI did not get involved in the project. He considered this would not only produce excessive dependence on what he termed "foreign elements" but also mean the banks would play a decisive role in the company's future thus "placing it completely outside State control [... ], leaving the Government without a say in a matter which affects our national defence and autarchy" 23

The Spanish government therefore had a very strong interest in manufacturing vehicles. The first step was to decide what models to produce and in what volumes. ${ }^{24}$ INI knew that the technological maturity of the industry and large world production volumes precluded setting up a home-grown car based on private initiative. Accordingly, it was decided to use "national interest" to justify a strongly interventionist approach. The regime considered that the industry's independence could only be guaranteed by keeping it out of the clutches of private enterprise. INI was convinced that Spanish car-making technology (once developed) would produce vehicles which were profoundly different to American or German products. Although Spanish car-making was heavily indebted to foreign technology, the belief was that Spanish manufacturing would soon achieve "national characteristics better suited to local problems (which was also the case when we drew on Italian technology) and our models will incorporate the features we find most useful". However, INI realised that it would be out of the question to design similar vehicles to those produced elsewhere in just three or four years without the help of companies like Ford, Mercedes Benz, Alfa Romeo, Chrysler and FIAT. Nevertheless, the Institute was 
eager to begin the manufacture of vehicles at the earliest opportunity, with an immediate start on lorries and preparation for car production within 3 - 4 years.

SIAT presented a project to the Ministry of Industry and Trade which involved setting up an automobile firm. However, both the Ministry and INI agreed that the Institute would take responsibility for setting up the motor industry, within the limits set by the legislation. INI's Board of Directors approved a major shareholding in the new Sociead Ibéica de Autamóiles de Tunismo (Spanish Car Company) in a decision taken on the $3^{\text {rd }}$ January 1942. It was also the intention that the State should take a fair slice of the profits from the venture. The following stakes were held in the company: SIAT: $25 \%$; other private companies: $15 \%$; and the remaining $60 \%$ in INI hands ${ }^{25}$. Once INI's participation had been decided, there remained the agreement terms which made the following provisions ${ }^{26}$ : (1) FIAT would provide all the patents and the widest possible technical support; (2) FIAT undertook to supply all the components required for manufacturing motors in Spain, and to produce chassis in the country within four years; (3) FIAT agreed to supply $66 \%$ of the machine tools used in Italy and draw up plans for their production in Spain; (4) It was proposed that FIAT supply second-hand machines from their factories to cover the remaining 33\% of special tools not made in Italy; (5) The new factory would manufacture the engine, chassis, transmission, and bodywork. Other components would be obtained from Spanish suppliers supported by INI and (where appropriate), with the technical help of FIAT; (6) FIAT would be remunerated for its services in the form of (a) royalties, paid in the form of shares and (b) a fixed sum per vehicle. Staff assistance would be paid for separately; 7) FIAT would supply up to $25 \%$ of the company's capital, the difference between paid up capital and royalties to be used to pay for machine tools; (8) If the contribution of FIAT and royalties exceeded $25 \%$ of shares - "which would desirable as a way of linking them more closely to the company", the excess could be paid in bonds bearing a fixed token interest rate, which would not be additional to any interest on shares; (9) approval was given for provisionally siting the factory in the Madrid industrial district.

FIAT in turn presented a contract which not only did not follow the scheme described above but also varied some of the clauses of the initial SIAT project, changes which, in the eyes of the INI Council, gravely prejudiced the interests of the Institute and did not comply with the legal provisions concerning capital. As a result, negotiations were suspended in August 1942 but were restarted in October when the Institute's Technical 
Commission, headed by Nadal and Sánchez Bautista of the Vehicle Department, interviewed representatives of FIAT at the company's Turin headquarters.

The war obviously hindered negotiations with FIAT but, in Suanzes' opinion "a "FIAT has been on the stocks for over two years now and is the only option open to us under the circumstances. It may well be that the end of hostilities will produce even greater difficulties [...] in implementing a project which is so tightly bound to concepts of autarchy and military interest" $^{27}$ (emphasis mine).

Eleven draft contracts were presented in the period up to April 1943. The last proposal, submitted on the $17^{\text {th }}$ April 1943, contained all of the changes requested by INI. The Spanish negotiators considered the new proposals highly acceptable, given that FIAT was no longer in a position to offer further trade-offs. It was therefore the moment to reach a final decision.

In INI's view, the motor industry "represented a symbol (underlined in the original) of a country's industrial development and essential to making tanks, gunboats, tractors, machine tools, and aeroplanes. The industry's symbolic importance and strategic importance to national defence and autarchy make it the keystone of the Institute's policy. (emphasis mine)" ${ }^{28}$ Consequently, the Council meeting of the $17^{\text {th }}$ April decided to ask the government for final authorisation in setting up a national car factory. ${ }^{29}$ However, Granell and Arburúa presented various objections to the application. Granell made various observations concerning the opportunities for building utility vehicles with FIAT. He added that the Institute could base such a proposal on a D ecree enacted in 1940, defining government policy regarding vehicle manufacture, and on instructions received at the beginning of 1942 from the Ministry of Trade and Industry regarding manufacture by a company with a majority INI stake (a point referring to the old SIAT project). Granell asked that the FIAT project be shelved, given the economic dislocation caused by the World War and the rising cost of plant which would doubtless be reflected in higher production costs. His argument was that offers could be obtained from other companies once hostilities ceased and thus have a positive impact on the cost of a plant and the time scale for executing the project. For his part, Arburúa argued that it was a bad time to start building utility cars with FIAT. In his opinion the World War would make it difficult for the company to meet its commitments. He also considered it easier to look for a solution 
once the war was over, when other foreign companies could provide competitive offers (and offer better terms than FIAT). ${ }^{30}$

In response to Granell's and Arburúa's observations, the then president of INI, General Suanzes, tartly commented that if things were put off every time the going got rough, the Institute's work would grind to halt and be limited to little more than supervising imports and patent licenses. He considered that "the motor industry is of paramount importance from both military and autarchic points of view" and reiterated that "it is pointless trying to establish other industries of national interest producing aeroplanes, armoured vehicles, and tractors without first setting up a car industry and an ancillary sector to serve its needs" ${ }^{31}$. Likewise, with regard to the FIAT patents, he argued that there were no prospects of other companies collaborating in setting up a Spanish car industry, besides which FIAT was the only European company which had managed to set up in the U.S. market. In addition, it already had experience of foreign collaboration with SIMCA in France, which turned out 20,000 vehicles a year. Moreover, no other European company had approached INI during the protracted negotiations with FIAT. Suanzes insisted that if this opportunity were missed there would be no chance of building vehicles after the war. The INI president's position was backed by consultants representing the military authorities, such as Dávila, Roa and F. Ávila, who stressed the strategic importance of the industry and its vital role as the basis for aircraft engines, tanks, etc. ${ }^{32}$

The military situation worsened in the last third of 1944 when German forces invaded Italy. The conflict that ensued brought the country grinding to a halt, effectively cutting Italy off from the outside world. This stopped the FIAT project in its tracks and also affected other ventures such as a scheme for building Alfa Romeo trucks. It also gave the impetus to an agreement between Hispano-Suiza and INI. Given that Italy was now effectively out of the game, the only project still in the running was Saurer's one for manufacturing trucks which was unfortunately too expensive to be considered a satisfactory solution. In addition, commercial difficulties with Switzerland might be made even worse by Germany. The latter country had repeatedly asked INI about Spanish truck needs. It seemed the immediate solution to the problem lay with either Daimler-Benz or $\mathrm{MAN}^{33}$. 
The FIAT car project was therefore shelved indefinitely. The problem was now how to build trucks and INI devoted all its efforts into this task. The result the foundation of the ENASA company [López Carrillo, 1996].

\subsection{Laying the foundations of the future Spanish motor industry, 1945-50}

Making cars in Spain had long been the aim of various state and private company schemes. One of the most important of these received the backing of the Urquijo group of industries. Urquijo focussed its attention on the creation of the SIAT company at the end of the Civil War. It sought technical support from FIAT for this purpose as well as from companies either forming part of the group or with links to it (e.g. D uro-Felguera, S.E. de Construcción Naval, Euskalduna, Basconia, S.E. de Construcciones Metálicas, Fundiciones Bolueta, Echevarría and Hispano-Suiza). SIAT bid in the public tender for automobile manufacture. The tendering competition was held in February 1940 but declared void for "foreign policy" reasons. However the Ministry of Industry asked for the project to be submitted again, this time under a "national interest" classification. However, a decision was postponed to "allow study to be made of the co-ordination between the SIAT and INI projects".

At the end of the Second World War INI concentrated projects for building industrial vehicles - trucks and tractors - in the recently established ENASA company. Just when it seemed that the Institute had dropped the idea of manufacturing cars (1947), the Urquijo group revived the SIAT project. This was based on four key points: (1) signing a wideranging technical co-operation agreement with FIAT, with training for Spanish staff; (2) reorganisation and modernisation of the metallurgical and machine making industries in the Urquijo group and associates (who would be involved in the project); (3) studying and planning ancillary industries; and (4) obtaining the lines of credit required for importing machinery.

Virtually a decade had passed when the old SIAT project was revived in 1947. All that was needed was the green light from the Ministry of Industry. Once again, Urquijo was told that the Government would only favour private initiative if it fitted in with INI's aims. The end result was that no authorisation was granted for isolated projects ${ }^{34}$. Even worse, the Banco Urquijo was told in no uncertain terms that its initiative "might awaken ambitions in FIAT which would be best thwarted" 35 . The Council of Ministers, meeting on the $24^{\text {th }}$ July 1947, agreed to reject Urquijo's project to manufacture utility vehicles using FIAT, 
unless INI were brought into the scheme and controlled the technical and financial side of the business. The reasoning behind this decision was "that it is not considered fitting to put the business exclusively in private hands given the enormous demand for vehicles in the Spanish market" ${ }^{36}$.

The Urquijo group was unwilling to be left out of a project which it had been working on for almost a decade. It was therefore willing to collaborate on the terms envisaged by the Council of Ministers, with INI and FIAT participation. However, INI considered it vital it should hold the controlling interest, at least until the new company was up and running and agreement could be reached on a division of responsibilities. The idea was that Urquijo would have a minority stake in the company but would be expected to take an active role in the running of the firm. For its part, Urquijo expected INI to grant it the controlling interest in the company once the firm was put in the hands of private enterprise ${ }^{37}$.

On this understanding, the final contract between INI and FIAT was signed on the $24^{\text {th }}$ November 1948. The venture was later to form the core of SEAT. The Italian company began casting around for a suitable site for the new factory. There could be little doubt about the best location. It had either to be in Northern Spain (the Basque country, Santander, or Asturias) or Barcelona and its hinterland ${ }^{38}$. Bilbao offered clear advantages in Northern Spain given its well-established steel industry and a labour force which could easily adapt to the demands of the motor industry. However, other considerations weighed in Barcelona's favour (mainly better communications with Italy, the advantages of siting the factory next to Spain's biggest Mediterranean port, skilled labour, and a good base for building up ancillary industries). The only drawback to Barcelona was the lack of a steelmaking industry, however this could be overcome if Sagunto was used for supplying materials. The siting issue is of particular interest because it broke with the regime's policy of avoiding Barcelona for purely political reasons ${ }^{39}$. Once Barcelona had been decided on, there was the question of where exactly the factory should be sited. At that time, the most industrial area of Barcelona was sandwiched between the River Besòs and the districts of Sant Andreú and Sant Adrià However, this was ruled out for three reasons: (1) exorbitant land prices, (2) the need for over three metres of land fill to avoid flooding from the river, and (3) the distance to the port, which would mean transporting items through the city's narrow, congested streets. Accordingly, the new factory site chosen was in the Free Port 
(thus making lading and unlading operations much easier) where land was cheaper and available in greater quantities.

\section{CONCLUSION}

Spain's came out of the Civil War with its industry virtually intact. It could have taken advantage of this to develop a motor industry. However, an interventionist and autarchic strategy and (to a lesser extent) the Second World War led the Franco regime to allocate resources in a singularly inefficient fashion [Tortella, 1995, p. 269, 272].

In this paper we have examined the various projects for manufacturing cars in Spain. The Government was already strongly committed to developing the motor industry at the end of the Civil War (1939) since it provided crucial underpinning for strategic sectors and an autarchic economic policy. Both considerations weighed heavily with the new fascist regime. Nevertheless, it was private initiative which first showed interest in the idea. On the one hand, foreign multinationals, including Ford and General Motors, had assembled vehicles in Spain during the period between the two World Wars. However, Spain's enthusiastic support for the Axis powers put the American companies at a clear disadvantage. There were also local initiatives, which can be placed under two heads: those which were purely Spanish, and those which required foreign support. The Urquijo project backed by FIAT technology and know-how was the most important of the latter type ${ }^{40}$. The Urquijo group quickly saw its interests threatened by the recently created INI. The Institute decided to lead an automobile-making project, draw up the SIAT scheme and begin negotiations with FIAT. The war and the invasion of Italy meant talks had to be suspended. INI then explored other options despite this setback. The blow to the scheme for building cars meant the truck manufacturing project was thrust to the fore. However, these plans also relied on striking a deal with Alfa Romeo. With Italy succumbing to Allied attacks in the South and German invasion from the North, plus fierce fighting between fascists and partisans, Italian companies were in no state to do business with anyone. However, there was an important difference between the car and truck projects. The former involved setting up a new car plant whereas the second could use existing facilities like the Hispano-Suiza factory. In fact, the Alfa Romeo project was a tripartite one involving INI, Hispano-Suiza, and Alfa Romeo, led by W. Ricart (head of the recently created CETA), among others. The result was ENASA, which started turning out trucks in 1946. 
After protracted negotiations between INI and FIAT, preliminary agreement was reached in 1943, however contact between the two parties was interrupted by the aftermath of the Italian surrender, only being resumed from 1947 onwards. The Urquijo group once again provided the catalyst for resumption of negotiations. FIAT and Urquijo agreed a contract in June 1947 for the manufacture of building utility vehicles. This came as surprise to INI which had been completely unaware of the negotiations. INI reacted by telling Urquijo that it wanted a majority stake in any such venture. Urquijo was forced to negotiate with INI. This was reflected in the contract struck by the former with FIAT in a clause which stated the deal would only take effect after receiving authorisation from the Spanish Government. This permission was denied. Finally, the contract was signed by FIAT and a mixed company with stakes held by INI and the Urquijo group.

Thus the motor industry was established with the creation of ENASA in 1946, followed by SEAT in 1949. The two most important sectors (basic trucks and cars, respectively) were now covered. This only left tractor manufacture to be tackled, plus some work on completing the truck range. This gap was bridged by Motor Ibérica (former Ford Spanish subsidiary), in 1954.

\section{BIBLIOGRAPHY}

Carreras, A. (1984), «La producción industrial española, 1842-1981: cosntrucción de un índice anual», Revista de Historia Económica, 2, 1, pp. 127-57.

Carreras, A. (1989), Estadísticas históricas de España, Fundación BEE, Madrid.

Catalan, J. (1989), «Autarquía y desarrollo en la industria de fábrica durante la Segunda Guerra Mundial. Un enfoque comparativo» in J.L. García D elgado (ed.), El primer franquismo, España durante la Segunda Guerra Mundial, Siglo XXI, Madrid.

Catalan, J. (1995), La Economía Española y la Segunda Guerra Mundial, Ariel, Barcelona.

Estapé-Triay, S. (1997), The Dynamics of the Firm in a Changing Environment. A Case Study on Ford and the Spanish Motor Industry in Historical Perspective, 19001990, Ph.D. Thesis, European University Institute, Florence.

Estapé-Triay, S. (1998), «Economic Nationalism, State Intervention, and Foreign Multinationals: the case of the Spanish Ford Subsidiary, 1936-54», Essays in Economic and Business History, XVI, pp. 53-74.

Estapé-Triay, S. (1998b), «Estrategia y organización de una filial: el caso de Ford Motor Company en España, 1920-54» Fundación Empresa Pública, Documento de trabajo, 9807, Madrid 
Ferguson, N. (1997), «ntroduction» in N. Ferguson (ed.) Virtual History: Alternatives and Counterfactuals, Picador

Fontana, J. (1986), España bajo el franquismo, Crítica, Barcelona.

García Delgado, J.L. (1987), «La industrialización y el desarrollo económico de España durante el franquismo», in Nadal, J., Carreras, A. And C. Sudrià (eds.), La economía española en el siglo XX. Una perspectiva histórica, Ariel, Barcelona.

López Carrillo, J.M. (1996) «Los orígenes de la industria de la automoción en España y la intervención del INI a través de ENASA», Fundación Empresa Pública, D ocumento de trabajo, 9608, Madrid

Martín Aceña, P. and F. Comín, (1997) El INI. 50 años de industrialización en España, Espasa-Calpe, Madrid.

Schwartz, P. and M.-J.González, (1978), Una historia del Instituto Nacional de Industria 1941-1976, Tecnos, Madrid.

San Román, E. (1995), «El nacimiento de SEAT: autarquía e intervención del INI», Revista de Historia Industrial, 7, pp. 141-65.

Tortella, G. (1995), El desarrollo de la España contemporánea. Historia económica de los siglos XIX y XX, Alianza, Madrid. 
TABLE 1. Autarchic automobile production plan, 1941

\begin{tabular}{|c|c|c|}
\hline & ASSEMBLY FACTORY & ENGINESFACTORY \\
\hline Years & $\begin{array}{l}\text { Assembly with parts } \\
\text { supplied by the ancillary } \\
\text { industry and imported }\end{array}$ & $\begin{array}{l}\text { Establishment of the } \\
\text { concern }\end{array}$ \\
\hline First & $\begin{array}{l}\text { Assembly of a reduced } \\
\text { number of vehicles with a } \\
\text { minimum of } 15 \% \text { of local } \\
\text { parts }\end{array}$ & $\begin{array}{l}\text { Projects and preliminary } \\
\text { work }\end{array}$ \\
\hline Second & $\begin{array}{l}\text { Increased of the production } \\
\text { Minimum of } 30 \% \text { of local } \\
\text { parts }\end{array}$ & Building of the facilities \\
\hline Third & $\begin{array}{l}\text { Further increased of the } \\
\text { production and } 45 \% \text { of } \\
\text { local parts }\end{array}$ & $\begin{array}{l}\text { Installation of the } \\
\text { machinery }\end{array}$ \\
\hline Fourth & Maximum of local parts & $\begin{array}{l}\text { Testing machinery, } \\
\text { resolution of the raw } \\
\text { materials supplies and } \\
\text { starting production } \\
\text { activities }\end{array}$ \\
\hline Fifth & \multicolumn{2}{|c|}{ Minimum production of 5.000 vehicles totally 'national' } \\
\hline
\end{tabular}

TABLE 2. Comparisons between the size of EUCORT -planned and actual- and the SEAT project

\begin{tabular}{llll}
\hline & EUCORT & EUCORT & SEAT \\
& Forecast, 1946 & Real, 1949 & Forecast, 1949 \\
\hline Capital (PTA) & 30 millions & 20 millions & 250 millions \\
Annual Production & 6.000 & 500 & 12.000 \\
Num. Employees & 4.200 & 730 & 6.000 \\
Facilities (sq.m.) & n.a. & 10.200 & 80.000 \\
Price (PTA) & 23/ 25.000 & $75 / 70.000$ & $50 / 60.000$ \\
\hline
\end{tabular}

Source: own elaboration based on data from «Report on EUCORT» by José Ortíz Echagüe, 3 August 1949, and «Report on EUCORT» by Jaime N adal, 13 March 1946, 355, INI Archives, Madrid. 
1 For the INI (National Industry Agency), see Schwartz and González (1978), Martín Aceña and Comín (1991).

2 In addition to cars and trucks, one ought to mention tractors. Trucks were the easiest on which to make start since the Hispano-Suiza factory was used to set up ENASA under INI auspices. A car factory presented much greater difficulties and in fact the project did not come to fruition until the creation of SEAT. With regard to tractors, Motor Ibérica played an important role. The company was privately funded by Spanish capita. Motor Ibérica was founded in 1954 when Ford abandoned its Spanish subsidiary, Ford Motor Ibérica.

3 Robert 1943, SEAT section 355, folder 8, INI Archive, Madrid.

4 The Decree of 3rd July 1931 established a system of tariff discounts for vehicle parts for assembly in Spain but for which a greater proportion of local components would have to be used in the future. The Decree of 10th December 1931 restricted the application of these discounts, establishing that 70\% of local components (by weight) had to be used within 6 years. The discounts applied were now calculated according to the percentage of local production achieved. These steps were undoubtedly a response to foreign manufacturers incorporating token local items in their imported vehicles.

5 Paper "Ofiaal”, Box 7531, Ford Motor Ibérica Archive (henceforth as FMI Archive), Barcelona

6 "Report to the G eneral Manager of FMI regarding the activities during the civil war" Box 7557, FMI Archive, Barcelona.

7 "Letter to the General Secretary of Industry", 7 September 1939, Box 7531, FMI Archive, Barcelona.

8 Elston (1976, pp. 191-193)

9 "Interview Mac-Gurk", section 243, tome 1, folder 2ª , INI Archive, Madrid

$10 \mathrm{ibid}$.

${ }_{11}$ D eclared an industry of national interest, D raft D ecree, Board of Industry, Ministry of Trade and Industry, and Tourism, 11 th December 1941, SEAT section, folder 5, INI Archive, Madrid

13 The EUCORT Board members were Eusebio Cortés Chertó (President), Carlos de la Caudra y Escrivá de Romaní, Joaquín Coll Fuster, Gregorio Prieto Capón, and Facundo Sarrí Sala

14 "Antecedentes, situación y perspectiva de la fabricación de automóviles Eucort", 1949, 232/ 3, INI Archive, Madrid.

${ }^{15}$ It should be noted that SIAT had had a similar request turned down in 1942, despite offering much greater guarantees since it held patents for the FIAT 1100 and had capital of 125 million Pesetas

16 "Request for the deckaration of industry of 'national interest' by Eusebio Cortés - 'Automóviles Eurcort'», Automobile D epartment, 13 March 1946, 242/ 4 INI Archive, Madrid.

17 “Communication from D irection CETA to Vice-Presidency INI», 3 September 1947, 242/ 4, INI Archive, Madrid

10 Letter «Luis Carrero, Government Presidency to INI's President» 20 June 1949, 242/ 4, INI Archive, Madrid.

18 ibid.

19 «Head Office's report to INI's Presidency», 12th September 1949, 242/ 4, INI Archive, Madrid

20 Ibid. 
21 «etter from EUCORT to the INI»,21 June 1950 and «Mr. Planell's private letter particular to Eusebio Cortés», 23 June 1950, 242/ 4, INI Archive, Madrid.

22 «Confidential banking report regarding EUCO RT's financial situation», 29 July 1949, 355/ 14, INI Archive, Madrid.

23 «Report on the manufacture of a utility vehicles - SIAT», March 1942, SEAT, folder 6, INI Archive, Madrid.

${ }^{24}$ Indicated in a note from the Automobile Department to the INI Vice-President, 14 October 1943, SEAT section 355, folder 20, INI Archive, Madrid.

25 Minutes of the INI Board meetings concerning the manufacture of cars in Spain (henceforth as ACAINI), section 2143, volume 1, folder 1, INI Archive, Madrid.

${ }^{26}$ ACAINI, 27th March 1942, INI Archive, Madrid.

27 ACAINI, 13th November 1942, INI Archive, Madrid.

28 ACAINI, 21st May 1943, INI Archive, Madrid.

29 In addition to the utility car venture, one should also not the negotiations with Alfa Romeo and Saurer (and in some respects with Hispano-Suiza) regarding truck manufacture.

30 ACAINI, 9 July 1943, INI Archive, Madrid.

31 Ibid.

32 Ibid.

33 «D etails of a meeting held with the INI President's Department», 21 March 1944, 243/ 1/ 1, INI Archive, Madrid.

34 «Note summarising discussions with the representatives of Bank of Urquijo in May 1948», Planell-FIAT section, folder 15, INI Archive, Madrid.

35 Ibid.

36 «Letter from the Ministry of Trade and Industry to Joaquín Planell, INI Vice-President», September 1947, Planell section, folder 15, INI Archive, Madrid.

37 «Note summarising discussions with the representatives of Banco Urquijo», May 1948, PlanellFIAT section, folder 15, INI Archive, Madrid.

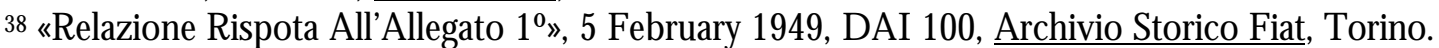

39 Ibid.

40 Relations between the Spanish Government and the Ford subsidiary were maintained throughout the early years of the Franco regime. I have covered these elsewhere [Estapé-Triay, 1997, 1998, 1998b]. General Motors, on the other hand, quickly abandoned its investments in Spain when its factories in Barcelona were closed during the Civil War. It did not return until 1980. 